\title{
RANCANGAN PROGRAM PELATIHAN UNTUK MENINGKATKAN SELF EFFICACY NEGOSIASI PADA SISWA SMK
}

\author{
Syarvia \\ UIN Alaudin Makassar, Jl. Sultan Alauddin No. 63 \\ e-mail: syarvialukman@gmail.com
}

\begin{abstract}
This research aimed to develop a training design to increase self-efficacy on negotiation for students of vocational school. Research subjects were 18 students of the SMK 1 Bandung class of 2011 marketing majoring. The design of the training program was conceived and developed with reference to the strength aspect of self-efficacy and negotiation, by applying the model of experiential learning. The training material organized into two main activities to improve selfefficacy in negotiation namely our business and making a profit. The effectiveness of the training is measured by the increase of self-efficacy category by using an instrument on negotiation selfefficacy, behavioral observation and evaluation of training. This study used a quasi-experimental method with the untreated control group pretest and posttest sample dependent design. T-Test results showed there's no significant improvement in the category of self-efficacy negotiations after the training program. Quantitatively and observations during training showed an increase in self-efficacy negotiation in aspects of communication, strategy and relationships, as well as a decrease in the emotional aspects among training participants.
\end{abstract}

Keywords: Self-efficacy, negotiation, training

\begin{abstract}
Abstrak
Penelitian ini bertujuan untuk membuat rancangan program pelatihan untuk meningkatkan self efficacy negosiasi pada siswa SMK. Subjek penelitiannya adalah siswa SMKN 1 Bandung jurusan pemasaran angkatan 2011, yaitu 18 siswa. Rancangan program pelatihan disusun dan dikembangkan dengan mengacu pada aspek self efficacy 'strength' dan negosiasi, dengan menerapkan model experiential learning. Materi pelatihan disusun menjadi 2 aktivitas utama untuk meningkatkan self efficacy dalam negosiasi yaitu 'our business \& making a profit'. Efektivitas dari pelatihan diukur dari peningkatan kategori self efficacy dengan menggunakan alat ukur self efficacy negosiasi, observasi perilaku dan evaluasi reaksi terhadap pelatihan. Penelitian ini menggunakan metode penelitian kuasi eksperimen dengan desain penelitian untreated control group design with dependen pretest and posttest sample. Hasil uji T-Test menunjukkan peningkatan yang tidak signifikan pada kategori self efficacy negosiasi setelah mengikuti program pelatihan. Secara kuantitatif dan hasil observasi selama pelatihan menunjukkan adanya peningkatan self efficacy negosiasi dari aspek komunikasi, strategi dan relasi, serta penurunan aspek emosi pada subjek yang mengikuti pelatihan.
\end{abstract}

Kata kunci: Self efficacy, negosiasi, pelatihan

\section{PENDAHULUAN}

Siswa SMK diharapkan tidak mengalami masalah dalam memilih dan mendapatkan pekerjaan. Hal ini mengingat bahwa siswa SMK sudah disiapkan untuk memasuki lapangan kerja dan mengembangkan sikap professional, mampu memilih karir, mengembangkan diri, berkompetisi, dan mengisi kebutuhan dunia usaha dan industri pada saat ini dan masa mendatang. Keyakinan akan kemampuan diri pada akhirnya berperan dalam keputusan karir dan bagaimana siswa menghadapi kesulitan yang ditemui saat merencanakan maupun menjalani karir yang dipilih, sehingga dibutuhkan suatu program yang dapat membantu siswa agar tetap sesuai dengan dunia kerja yang sesungguhnya, yaitu yang dapat menyelesaikan pekerjaan sesuai dengan tuntutan yang berlaku.

Alumni pemasaran diharapkan akan menjadi pihak yang paling berperan dalam sukses atau tidaknya marketing di suatu perusahaan sekaligus menjadi pihak 
perantara antara perusahaan sebagai penyedia barang dengan konsumen (masyarakat) yang membutuhkan. Untuk itu kemampuan komunikasi yang memadai sangat dibutuhkan dalam mencapai harapan bersama.

Berdasarkan eksplorasi permasalahan di SMK 1, khususnya untuk jurusan pemasaran, dengan latar belakang jurusan yang kurang populer dan pemahaman tentang tuntutan di jurusan yang kurang berdampak pada keyakinan diri yang umumnya masih rendah. Hal ini juga disebabkan dari pengalaman belajar yang didapatkan belum sesuai dengan tuntutan sebenarnya. Siswa memerlukan intervenesi untuk mengembangkan keyakinan diri mereka dalam hal kemampuan negosiasi, karena itu adalah salah satu hal dasar yang dibutuhkan sebagai seorang marketer atau pihak pemasaran. Negosiasi adalah suatu interaksi yang dilakukan untuk mencapai kesepakatan bersama. Negosiasi tidak hanya dalam konteks pemasaran, secara sederhana dapat dilihat ketika seseorang melakukan interaksi dengan orang lain, baik bernegosiasi masalah pembagian tugas, waktu maupun hal-hal tertentu yang terkait dengan kedua belah pihak.

Berdasarkan permasalahan ter-sebut, maka peneliti merancang suatu program intervensi untuk membantu siswa jurusan pemasaran dalam menghadapi pilihan karirnya setelah menyelesaikan studi di SMK. Bentuk intervensi yang dipilih oleh peneliti adalah berbentuk program pelatihan yang berdasarkan teori self efficacy dari Bandura sebagai materi pembelajaran, yang bertujuan untuk meningkatkan self efficacy dalam melakukan negosiasi.

\section{KAJIAN TEORI}

Konsep self efficacy pertama kali dikemukakan oleh Bandura pada tahun 1977. Berikut ini akan disajikan beberapa definisi self efficacy yang berbeda walaupun semuanya merupakan perluasan dari definisi Bandura.
1. Schunk \& Pajares (Wentzel \& Wigfield, 2009) mengutip pernyataan Bandura (1997) bahwa self efficacy refers to perceived capabilities for learning or performing actions as designated level, yang artinya me-ngacu pada perasaan mampu untuk belajar atau mengambil tindakan pada tingkat tertentu.

2. Pajares (1996), dari Bandura (dalam Wentzel \& Wigfield, 2009) mengatakan bahwa 'beliefs in one capability to organize and execute the courses of action required to manage prospective situations', yang berarti kepercayaan individu mengenai kemampuannya untuk mengelola dan menetapkan suatu arah tingkah laku yang digunakan untuk mengatur situasi yang diinginkan.

3. Bandura (Sharf, 2006) menggambarkan self efficacy sebagai penilaian seseorang terhadap kemampu-an diri mereka untuk mengatur dan melaksanakan tindakan yang diperlukan dalam mencapai kinerja tertentu. Bagaimana individu melihat kemampuan dan kapasitas mereka yang akan mempengaruhi akademik, karier, dan pilihan lainnya.

4. Pervin (1993, dalam Bandura 1998) mengatakan bahwa, 'perception that one can perform the tasks required by a situation or cope with a situation' adalah persepsi bahwa individu mampu untuk menyelesaikan suatu tugas dalam situasi tertentu.

Meskipun definisi self efficacy dinyatakan secara berbeda, namun pada dasarnya memiliki makna yang sama, yaitu mengenai keyakinan individu akan kemampuannya untuk berhasil dalam melakukan sesuatu.

Negosiasi adalah proses dimana orang yang memiliki kebutuhan berbeda berusaha untuk mencapai kesepakatan yang spesifik dengan cara memberi dan menerima bagi satu sama lainnya (Johnson \& Johnson, 2009).

Negosiasi adalah istilah bahasa Indonesia yang diserap dari bahasa Inggris, 
yakni negotiate yang berarti merundingkan atau membicarakan kemungkinan tentang suatu kondisi atau tawar menawar. Katakata turunanya antara lain negotiable yang berarti dapat dirundingkan, dapat ditawar atau dibicarakan. Negosiasi merupakan proses atau aktivitas perundingan atau pembicaraan tentang sesuatu dengan orang lain (Sujana, 2004). Karena merupakan pembicaraan, maka dalam negosiasi harus terpenuhi syarat adanya dua orang yang saling berbicara satu sama lain. Karena merupakan perundingan atau tawar menawar, maka harus ada pihak yang menawar dan pihak yang ditawar, karena itu negosiasi harus mensyaratkan minimal dua orang yang saling berunding.

Pelatihan self efficacy negosiasi adalah program pelatihan yang dirancang dengan menggunakan prinsip belajar experiential learning. Materi pelatihan dibagi ke dalam 2 aktivitas utama yaitu 'our business' dan 'making a profit' yang dirancang untuk meningkatkan self efficacy negosiasi siswa SMK jurusan pemasaran.

\section{METODE PENELITIAN}

Penelitian yang dirancang dalam bentuk uji rancangan modul pelatihan ini termasuk field experimental research (penelitian eksperimen lapangan) yaitu penelitian yang dilaksanakan dalam situasi nyata, dengan memanipulasi satu variabel bebas (rancangan pelatihan self-efficacy) dalam kondisi yang dikontrol dengan cermat, sejauh yang dimungkinkan oleh situasi (Kerlinger, 1986). Mengingat dalam prosedur pengumpulan data dan kontrol atas semua stimulus tidak dapat dijalankan sepenuhnya, maka rancangan penelitian yang digunakan adalah quasi-experimental design, atau dikatakan juga sebagai pseudo experiment atau rancangan seolah-olah "menyerupai" eksperimen yang sebenarnya (true experiment, Matheson, Bruce \& Beauchamp, 1978).

Desain yang digunakan dalam penelitian "Rancangan Program Pelatihan untuk meningkatkan Self-efficacy (studi mengenai uji coba program self-efficacy dalam negosiasi yang mencakup strength pada siswa SMK 1 Bandung)" adalah untreated control group design with dependen pretest and posttest sample, yaitu menggunakan kelompok kontrol dan eksperimen dengan memberikan pretest dan posttest. Kelompok eksperimen mendapatkan treatmen berupa pelatihan self efficacy negosiasi.

Subjek penelitian adalah siswa SMK 1 Bandung angkatan 2011, khusus untuk jurusan Pemasaran dan bersedia untuk mengikuti pelatihan self efficacy. 1 kelas menjadi kelas uji coba alat ukur sekaligus kelompok kontrol dan 2 kelas yang menjadi subjek pelatihan atau kelompok eksperimen. Subjek penelitian dalam hal ini berjumlah 18 orang, 17 perempuan dan 1 laki-laki.

\section{HASIL DAN PEMBAHASAN}

Hasil Levene's Test menunjukkan bahwa nilai Levene's Test tidak signifikan (karena $p=0,880>0,05$ ), berarti varians dalam kedua kelompok adalah sama.oleh karena itu, nilai $\mathrm{t} \quad-0,737$ dengan signifikansi 0,001 , hal ini berarti nilai $\mathrm{t}$ signifikan $(\mathrm{p}=0,467<0,05)$, dengan kata lain self-efficacy negosiasi pada kedua kelompok tidak berbeda secara signifikan. Dengan demikian dapat disimpulkan bahwa pelatihan self-efficacy negosiasi yang diberikan tidak memberikan pengaruh untuk meningkatkan self-efficacy negosiasi siswa Jurusan pemasaran.

Berikut adalah gambaran kategori self-efficacy negosiasi antara kelompok kontrol dan kelompok eksperimen:

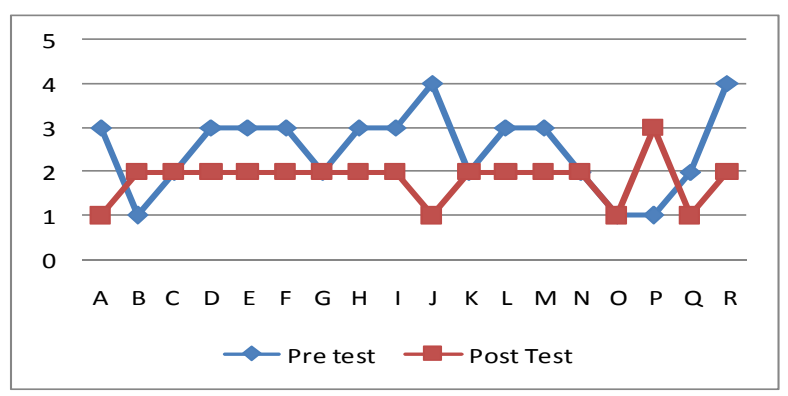

Grafik 1.1 Hasil Pretest-posttest kelompok kontrol 
Dari hasil pengukuran pada kelompok kontrol, didapatkan bahwa dari 18 subjek terdapat $61 \%$ (11 subjek) yang mengalami penurunan kategori selfefficacy, $28 \%$ (5 subjek) yang tidak mengalami perubahan kategori, dan sisanya adalah sekitar $11 \%$ (2 subjek) mengalami peningkatan kategori selfefficacy negosiasi.

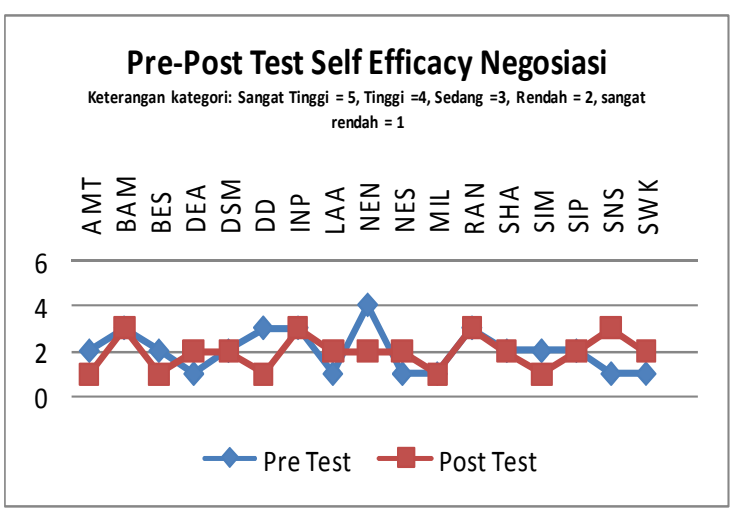

Grafik 1.2 Pretest-posttest Self-Efficacy

Negosiasi Kelompok Eksperimen

Grafik di atas menggambarkan bahwa sebelum melakukan pelatihan terdapat 6 subjek yang memiliki selfefficacy negosiasi dengan kategori 'sangat rendah', 6 subjek dengan self-efficacy negosiasi yang tergolong 'rendah', 4 subjek dengan self efficacy yang tergolong 'sedang', dan 1 subjek pelatihan yang memiliki self efficacy negosiasi 'Tinggi'.

Adapun gambaran persentase peningkatan self-efficacy negosiasi terhadap subjek penelitian (kelompok eksperimen) setelah mengikuti pelatihan adalah sebagai berikut:

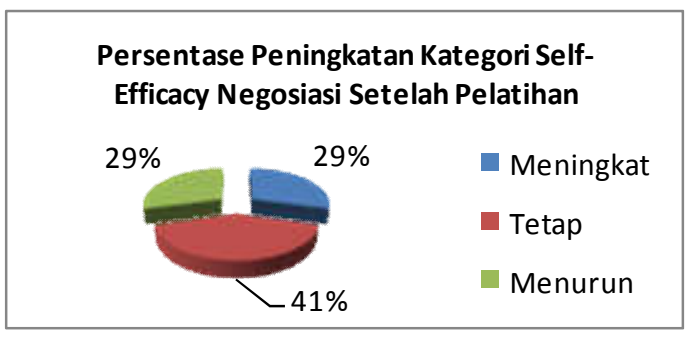

Grafik 1.3 Persentase Peningkatan Kategori Self-Efficacy Negosiasi Setelah Pelatihan
Berdasarkan grafik di atas dapat dilihat bahwa sebanyak 29.5\% (5 subjek) mengalami peningkatan kategori selfefficacy negosiasi, baik meningkat satu kategori ataupun lebih. 41\% (7 subjek) tidak mengalami peningkatan kategori (meskipun skornya meningkat), dan $29.5 \%$ (5 subjek) mengalami penurunan selfeffcicacy negosiasi setelah pelatihan tersebut.

Grafik-grafik berikut akan memberikan gambaran lebih jelas mengenai kondisi setiap subjek penelitian dari kelompok eksperimen, sebelum dan sesudah pelatihan berdasarkan empat aspek negosiasi. Aspek komunikasi adalah kemampuan untuk mengkomunikasikan, menjelaskan informasi dan memberikan pertimbangan mengenai produk yang ditawarkan. Aspek emosi adalah kemampuan untuk membuat diri dan orang lain merasa nyaman saat negosiasi, meskipun orang lain bereaksi negatif. Aspek relasi adalah kemampuan untuk bernegosiasi dan menyesuaikan diri dengan berbagai karakter, dan aspek strategi adalah kemampuan untuk membuat penawaran dan mencari berbagai alternatif untuk sama-sama saling menguntungkan.

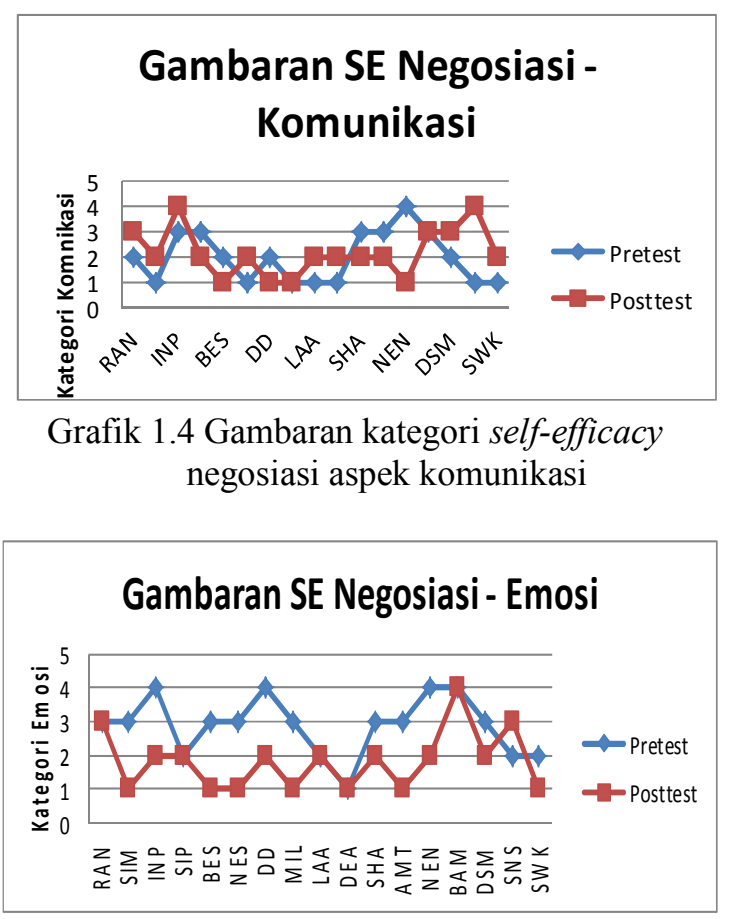


Grafik 1.5 Gambaran kategori self-efficacy negosiasi aspek emosi

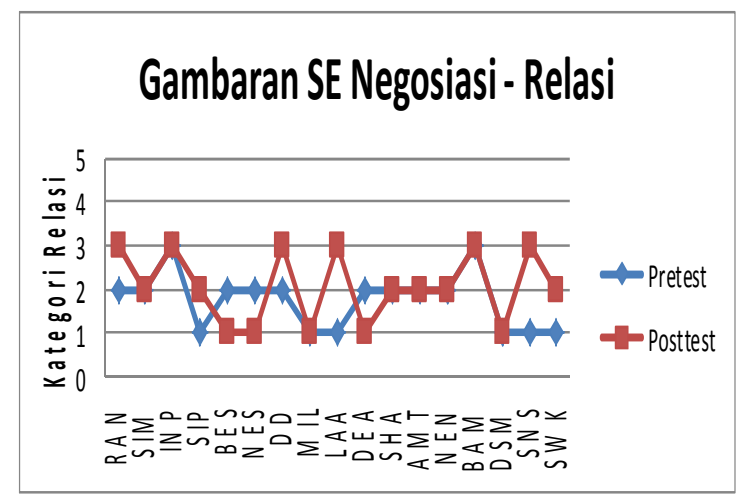

Grafik 1.6 Gambaran kategori self efficacy negosiasi aspek relasi

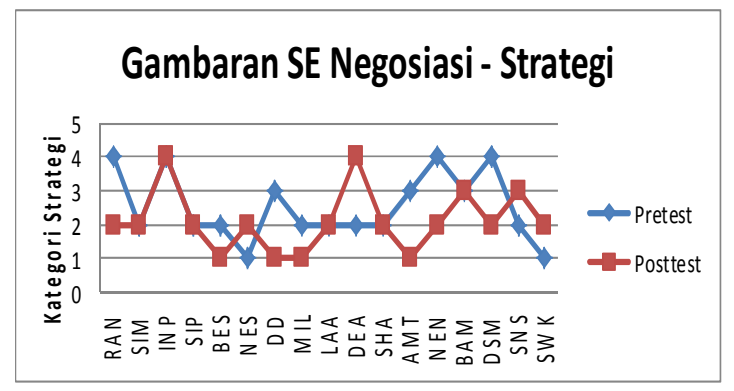

Grafik 1.7 Gambaran kategori self-efficacy negosiasi aspek strategi

Dapat disimpulkan bahwa dari 17 peserta pelatihan, sebanyak $53 \%$ mengalami peningkatan kategori aspek komunikasi, adapun pada aspek emosi 65\% mengalami penurunan. Sebanyak $35 \%$ subjek penelitian mengalami peningkatan kategori pada aspek relasi. Adapun pada aspek strategi hanya sebagian kecil atau sekitar $24 \%$ peserta pelatihan yang mengalami peningkatan.

Pengujian hipotesis menunjukkan bahwa hipotesis penelitian yaitu rancangan program pelatihan self-efficacy negosiasi dapat meningkatkan self-efficacy negosiasi pada siswa Jurusan Pemasaran ditolak. Dengan demikian dapat disimpulkan bahwa tidak terjadi peningkatan kategori self-efficacy negosiasi yang signifikan setelah diberikan pelatihan. Fokus peneliti- an ini adalah pengujian akan rancangan program yang telah dibuat, untuk itu berikutnya akan dibahas dengan lebih spesifik mengenai peningkatan yang terjadi pada empat aspek yang mendukung negosiasi. Secara umum, aspek komunikasi adalah aspek yang mengalami peningkatan dari peserta sebanyak 53\%, aspek relasi sebanyak $35 \%$, aspek strategi sekitar $24 \%$ dan aspek emosi meningkat sekitar 6\%. Dari keempat aspek tersebut, sebagian besar peserta pelatihan atau sekitar $65 \%$ mengalami penurunan kategori selfefficacy negosiasi (aspek emosi) setelah diberikan pelatihan.

Setelah mengikuti pelatihan, sekitar $29,5 \%$ (5 peserta) mengalami peningkatan kategori self-efficacy negosiasi, 41\% (7 Subjek) tidak mengalami peningkatan kategori dan 29,5\% (5 peserta) mengalami penurunan kategori. Dari hasil ketiga kelompok, dapat disimpulkan bahwa peserta yang mengalami peningkatan selfefficacy negosiasi, ditunjang dengan peningkatan aspek komunikasi, strategi dan relasi. Sedangkan peserta pelatihan yang mengalami penurunan self-efficacy negosiasi, disebabkan oleh penurunan kategori aspek emosi, strategi dan komunikasi. Berdasarkan hal tersebut, rancangan program yang dibuat menunjukkan kemampuan untuk me-ningkatkan aspek komunikasi, strategi dan relasi, sedangkan aspek emosi masih memerlukan stimulasi dan arahan kegiatan yang lebih spesifik.

Program pelatihan ini disusun dengan mempertimbangkan aspek-aspek yang membentuk self-efficacy dan aspek pembentuk negosiasi. Tahapan pelatihan mengacu pada prinsip belajar experiential learning yang memberikan pengalaman langsung untuk mengalami proses negosiasi sebagai upaya untuk meningkatkan self-efficacy negosiasi. Ditinjau dari kedua aktivitas yang diberikan yaitu 'our business' dan 'making a profit', dititikberatkan pada pengalaman komunikasi, strategi dan relasi. Hal ini kemudian menjawab permasalahan penurunan kate- 
gori aspek emosi pada self-efficacy negosiasi, karena rancangan yang dibuat kurang detil dalam mengontrol kegiatan yang memungkinkan peserta pelatihan mendapatkan pengalaman atau situasi emosional yang dapat menggugah selfefficacy negosiasi. Pada pelaksanaan pelatihan, ada satu peserta dari kelompok III yang mendapatkan kritik dari temanteman kelompoknya mengenai ketidaknyamanan saat melakukan negosiasi, hal ini cukup mempengaruhi jalannya negosiasi. Sedangkan pada dua kelompok lainnya tidak mengalami situasi tersebut. Situasi ini menggambarkan keterbatasan dari rancangan program yang kurang mempertimbangkan aspek tersebut dengan detil.

Untuk aktivitas 'our business' dilakukan percobaan negosiasi sebanyak 5 kali (5 ronde) dalam waktu 2 menit untuk setiap negosiasi. Tidak ada satupun peserta yang berhasil mencapai tujuan permainan ini, dari hal ini dapat disimpulkan bahwa 5 kali kesempatan tersebut ternyata belum mampu untuk membuat peserta mencapai target yang disampaikan. Umumnya peserta masih terpaku pada proses barter atau tukar poin, dalam arti 1 poin ditukar dengan 1 poin. Secara umum peserta juga belum mempertimbangkan strategi dan peluang yang dimiliki dalam melakukan negosiasi. Dari proses ini, dapat dikaitkan dengan aspek yang mempengaruhi selfefficacy yaitu enactive mastery experience yang merupakan aspek yang paling memberikan kontribusi besar bagi keyakinan diri individu (Bandura, 1997). Terbatasnya kesempatan untuk melakukan negosiasi menjadi salah satu faktor dari kegagalan peserta dalam mencapai tujuan dari permainan ini. Kegagalan yang berulang sebenarnya dapat meningkatkan selfefficacy, namun hal tersebut kembali lagi kepada individu yang bersangkutan, masing-masing membutuhkan kuantitas pengalaman yang berbeda.

Selain itu, faktor emotional arousal atau ambang ketergugahan emosi menjadi salah satu hal yang mempengaruhi self- efficacy (Bandura, 1997). Emosi negatif yang dirasakan dapat mempengaruhi keyakinan individu, dalam hal ini adalah perasaan kesal dan kecewa dalam proses negosiasi membuat individu menjadi tidak optimal atau menurunkan usahanya saat menemui kesulitan.

Pada aktivitas 'our business' ini sebenarnya diberikan instruksi khusus pada dua kelompok, yaitu kelompok I mendapatkan instruksi win-lose negotiation, kelompok II mendapatkan instruksi win-win negotiation, dan kelompok III tidak mendapatkan instruksi. Proses pemilihan kelompok yang mendapatkan instruksi ini dilakukan secara random, hal ini mungkin menjadi salah satu penyebab tidak tercapaianya tujuan dari aktivitas ini yang ingin memberikan pengalaman dan pemahaman langsung mengenai perbedaan kedua jenis negosiasi. Meskipun demikian, fasilitator me-nekankan hal tersebut saat penjelasan dalam kelas besar setelah aktivitas diberikan.

Melalui aktivitas 'making a profit', peserta banyak belajar dari pengalaman langsung yang hampir sesuai dengan kenyataan yang akan dihadapi di lapangan. Pengalaman berulang yang dirasakan memberikan pengaruh terhadap keyakinan diri mereka untuk melakukan negosiasi. Pengalaman dari ronde 1 dan ronde 2 , membuat peserta mampu mengukur kemampuan mereka untuk akhirnya membuat target dan menyusun strategi pada ronde berikutnya. Interaksi setiap peserta dalam kelompok juga memberikan pengalaman belajar 'modelling/vicarious learning' melalui orang lain yang bisa memberikan dampak positif terhadap keyakinan diri mereka. Begitupun umpan balik (verbal persuasion) yang didapatkan dari teman maupun co-fasilitator saat debrief. Selain itu suasana emosi atau ambang ketergugahan emosi masih menjadi salah satu aspek yang cukup menentukan keyakinan diri mereka dalam melakukan negosiasi.

Dari kedua aktivitas utama yang diberikan, secara umum peserta cenderung 
tidak mudah untuk memahami instruksi atau arahan kegiatan. Selain dijelaskan oleh fasilitator utama, juga diberikan tambahan penjelasan oleh co-fasilitator. Hal ini menjadi salah satu keterbatasan dari rancangan dan pelaksanaan pelatihan, sehingga mempengaruhi hasil dari pelatihan. Pada aktivitas 'our business' misalnya lembaran kerja yang diberikan dimaknai secara ambigu oleh sebagian besar peserta, khususnya pada bagian 'kelebihan dalam negosiasi'. Yang dimaksud dalam rancangan tersebut adalah kelebihan pribadi negosiator dalam melakukan negosiasi, tapi sebagian besar menjawab kelebihan dari proses negosiasi tersebut sehingga tidak semua peserta mampu menghayati kelebihan mereka dalam proses negosiasi yang dilakukan.

Karakteristik peserta penelitian yang merupakan remaja dengan usia sekitar 1617 tahun perlu menjadi perhatian utama dalam merancang suatu program pelatihan khususnya self-efficacy negosiasi. Hal ini disebabkan faktor emosi atau suasana hati masih cukup mempengaruhi aktivitas yang dilakukan. Ditinjau dari aspek emosi dalam negosiasi dan emotional arousal dalam self-efficacy, kondisi ini cukup mempengaruhi peningkatan self-efficacy negosiasi mereka.

Aktivitas pelatihan yang diberikan dalam bentuk kelompok secara tidak langsung mengarahkan peserta untuk belajar secara kooperatif untuk menggugah atau mempengaruhi penilaian mereka terhadap kemampuan yang dimiliki (Johnson, Maruyama, Johnson, Nelson \& Skon, 1981, dalam Bandura, 1997). Hal ini dilakukan dalam pelatihan, meskipun pada pelaksanaan aktivitas pertama cenderung masih bersikap kompetitif.

Berdasarkan siklus belajar experiential learning, peningkatan kategori self-efficacy negosiasi yang tidak signifikan dapat dijelaskan melalui tahapan generalizing yaitu tahapan ketika peserta mulai memunculkan prinsip-prinsip atau generalisasi dari pengalaman yang sudah dilalui saat pelatihan. Pemaknaan dari setiap pengalaman dalam pelatihan dan insight mengenai keterkaitan pengalaman terhadap situasi nyata yang mereka hadapi dalam kehidupan sehari-hari. Hanya sebagian kecil peserta yang mampu memberikan insight saat pelatihan berlangsung, baik pada proses debrief maupun dalam proses tanya jawab dengan fasilitator. Untuk itu tahapan ini perlu mendapat perhatian khusus, mencari cara yang tepat untuk menggugah insight dari peserta pelatihan, agar proses belajarnya bisa sampai pada tahapan applying.

\section{SIMPULAN}

Berdasarkan analisa hasil yang diperoleh dalam penelitian ini, maka diperoleh kesimpulan sebagai berikut:

1. Rancangan pelatihan self efficacy negosiasi yang diberikan tidak dapat meningkatkan self efficacy negosiasi secara signifikan pada siswa jurusan pemasaran angkatan 2011, SMKN 1 Bandung.

2. Aktivitas pelatihan yang menggunakan pendekatan experiential learning dan metode simulasi atau role play merupakan metode yang sesuai untuk memfasilitasi proses belajar self efficacy pada anak SMK.

3. Rancangan program pelatihan self efficacy negosiasi cenderung mampu meningkatkan aspek komunikasi, strategi dan relasi, tapi belum mampu meningkatkan aspek emosi dalam negosiasi.

4. Aspek enactive mastery experience cukup mampu memberikan pengaruh dalam self efficacy negosiasi kepada subjek pelatihan.

5. Aspek emotional arousal cukup mendominasi subjek pelatihan (remaja) dan memberikan pengaruh dalam pelaksanaan pelatihan dan self efficacy negosiasi.

Saran yang dapat diberikan dalam penelitian ini adalah:

1. Diberikan pelatihan yang serupa secara berkala, dengan pertimbangan bahwa untuk peningkatan self efficacy 
negosiasi diperlukan proses belajar yang kontinyu dan ditunjang dengan praktek negosiasi secara berkala.

2. Perlu diberikan penambahan jumlah 'ronde' pada setiap aktivitas untuk lebih memberikan 'experiential learning' dan pertimbangan untuk memberikan aktivitas berdasarkan level tingkat kesulitan.

3. Perlu dipertimbangkan masalah waktu pelatihan dan penambahan materi yang ditampilkan melalui video.

4. Pihak terkait, dalam hal ini SMKN 1 Bandung jurusan pemasaran perlu memberikan program khusus yang melatih negosiasi, khususnya untuk siswa angkatan akhir.

5. Peneliti yang tertarik untuk memberikan intervensi terkait dengan self efficacy, perlu mempertimbangkan waktu pelatihan, instruksi dan karakteristik subjek penelitian.

\section{DAFTAR PUSTAKA}

Azwar, S. 2013. Penyusunan Skala Psikologi (edisi 2). Yogyakarta: Pustaka Pelajar

Azwar, S. 2004. Validitas dan Reliabilitas. Yogyakarta: Pustaka Pelajar

Bandura, A. 1977. Social Learning Theory. New Jersey: Prentice-Hall, Inc.

Bandura, A. 1997. Self Efficacy (The Exercise of Control). New York: W.H Freeman and Company

Bandura, A. 2006. Self Efficacy Beliefs of Adolescent (307-337). Age Publishing

Christensen, L. B. 1988. Experiential Methodology $4^{\text {th }}$. Massachusets: Allyn and Bacon, Inc.

Friedenberg, L. 1995. Psychological Testing: Design, Analysis and Use. Massachusetts: Allyn \& Bacon.

Goldwich, D. 2010. Win-win Negotiations. Singapore: Marshall Cavendish Business.
Graziano, AM \& Raulin, M. L. 2000. Research Methods of Process of Iquiry. : Allyn \& Bacon.

Hayadin. 2006. Pengambilan Keputusan untuk Profesi pada Siswa Jenjang Pendidikan Menengah (Studi pada SMA, MA, \& SMK di DKI Jakarta).

Hurlock, E. 2002. Psikologi Perkembangan; Suatu Pendekatan Sepanjang Rentang Kehidupan. Jakarta: Erlangga.

Johnson, D. W \& Johnson, F. P. 2009. Joining Together $10^{\text {th }}$ Edition Group Theory and Group Skills. New Jersey: Pearson Education.

Kirkpatrick, Donald L \& James D Kirkpatrick. 2006. Evaluation Training Program: The Four Level $3^{r d} E d$. San Francisco: BerretKoehler Publisher.

Lee, C \& Bobko, P. 1994. Self-efficacy beliefs: Comparison of five measure. Journal of Applied Psychology, 79, 364-369.

Pfeiffer, J. William \& John E., Jones. 1979. The 1979 Annual Handbook For Group Facilitators. California: University Associates Inc.

Santrock, W. 2003. Adolescence 'Perkembangan Remaja'. Jakarta: Erlangga.

Sanusi, M. 2011. Negosiasi Cerdik Ala Nabi. Jogjakarta: Bening

Shadish, W. R., Cook, T. D \& Campbell, D. T. 2002. Experimental and Quasi Experimental Designs. Belmont: Wadsworth

Sharf, R. S. 1992. Applying Career Development Theory to Counseling. California: Brooks/Cole Publishing Company.

Sharf, R. S. 2006. Applying Career Development Theory to Counseling. Canada: Thomson Brooks/Cole.

Seniati, L., Yulianto, A \& Setiadi, B. N. 2009. Psikologi Eksperimen. Jakarta: PT. Indeks

Susiati, E. 2008. Tesis. Hubungan Self Efficacy dengan Kematangan Karir pada Siswa kelas X SMA Negeri 8 
Bandung (Studi Program Bimbingan Karir bagi Pengembangan Self Efficacy \& Kematangan Karir Siswa). Bandung: Universitas Pendidikan Indonesia.

Syamsuddin, A. M. 2005. Psikologi Kependidikan. Bandung: PT. Remaja Rosdakarya

Vernoy, M \& Kyle, D. 2002. Behavioral Statistics in Action 3rd Ed. USA: Mc Graw Hill.

Walters, G. A \& Marks, S. E. 1981. Experiential Learning and Change; Theory, Design and Practice. Canada: John Wiley \& Sons.
Wentzel, K. R \& Wigfield, A. 2009. Handbook of Motivation at School. Oxon: Taylor \& Francis Group.

Wina, N. 2010. Skripsi. Profil Self Efficacy Karir Peserta Didik; Studi Deskriptif ke arah Program Pengembangan Self Efficacy Karir Siswa Kelas XI SMA Negeri 1 Lembang.

Yusuf, S. 2005. Landasan Bimbingan dan Konseling. Bandung: PT Remaja Rosdakarya. 